\title{
Orthodoxy as an Educational Tool in Prerevolutionary Russia
}

\author{
Vadim Zubov \\ Financial University under the Government of the Russian Federation \\ Moscow, Russia \\ E-mail: zubov305@yandex.ru
}

\begin{abstract}
The paper considers the formation and development of education system in the Russian Empire in the 18th - early 20th centuries. During the Peter the Great period, parochial schools were established, several private general education schools and secondary special educational institutions. In the second half of the 18th century and the beginning of the 19th century, the first universities appeared in Russia. In the second half of the 19th century, the Russian Empire formed the educational system, including higher, secondary and primary educational institutions, represented by universities, gymnasiums, county and parish schools. Particular attention is paid to the analysis of the importance of Orthodoxy in the process of formation and development of the education system of the Russian Empire and its consolidating role in the Russian state in the pre-revolutionary period.
\end{abstract}

Keywords-Orthodoxy; educational system; prerevolutionary Russia; Petrine reforms; autocracy; social progress

\section{INTRODUCTION}

For the first time the issues of education were addressed by Peter I. In the course of the reforms czar-innovator faced the gravest of issues - almost universal illiteracy of the population. After ascending to the throne and planning his reforms, Peter I suddenly discovered that: "there is no place to teach, no one to teach and no one to be teacher" [1]. The majority of his subjects didn't know the most elementary things: couldn't read, write, were not able to do the simplest calculations. Depending on the membership in one, or the other caste, people of that time only had knowledge that they received from their parents, or their "elders". And if until the abolition of serfdom illiteracy of commoners did not disturb anyone, and even was considered a mercy since an educated man would have a harder time living as a serf slave, the illiteracy of their masters and clergy concerned the autocracy. As it is known, human is a social being. And every socium is held by certain rules and laws. And if nearly entire country population is illiterate, then religion becomes the main social "clasp" of the socium

\section{FORMATION OF THE EDUCATION SYSTEM DURING THE PETER I ERA}

Even though the issue of illiteracy in Russian State, as an issue that halted the development of the Empire, was found out by Peter I, neither neither he nor his successors were able to solve it overnight. According to the Population Census of 1897 (more than 150 years after his death), $76 \%$ of the populace of Russian Empire still were illiterate. Moreover, it should be noted that the term "literacy" at the same time was perceived differently by different people. For example, here is the percentage of illiterate conscripts in Russia:

TABLE I. The PERCENTAge of ILliterate CONSCRIPTS IN RUSSIA

\begin{tabular}{|c|c|c|c|c|}
\hline Years & $\mathbf{1 8 9 6}$ & $\mathbf{1 9 0 0}$ & $\mathbf{1 9 0 5}$ & $\mathbf{1 9 1 3}$ \\
\hline $\begin{array}{c}\text { \% } \\
\text { illiterate }\end{array}$ & $60 \%$ & $51 \%$ & $42 \%$ & $27 \%$ \\
\hline
\end{tabular}

The draft commissions of Russian army clearly segregated literate (those who could both read and write), semi-literate (could only read) and illiterate (couldn't read or write) [2]. And this is despite the fact that the students of the network of educational institutes received knowledge in several disciplines. This means, it was about factual ability of a conscript to read or write, and not him graduating an institution. Neither has it seemed that the quality of reading and writing was thoroughly tested.

Peter I began the formation of educational system in Russian Empire with his decree of 1710 about opening parochial schools in every parish. But the execution of this decree was proven impossible because of lack of financial and management resources. There were no books, no money to build school buildings, no resources for maintenance of pedagogical stuff, and there were no teachers as well. This decree has remained unfulfilled. The issue of organization of universal education in Russian Empire turned out to be more complex that it appeared to Peter Alekseevich at first. Under Peter I, several private general education schools appeared. In 1793, Moscow Gymnasium of pastor Gluk had opened, in which following disciplines were taught: 5-6 foreign languages, geography, mathematics, physics, rhetoric, history and politics. In 1721, Theophanes Prokopovich had established the St. Petersburg school for orphans and poor children, in which four languages, geography, mathematics, logic, rhetoric, history, music and drawing were taught. But this was only the beginning of the formation of the education system. At first, Peter I approved and even financed such projects, but later on the financing stopped since the Emperor was aiming for much quicker results than those these schools and gymnasiums could provide. Peter I had projects that required immediate execution and personnel with higher 
education, yet he did not have enough executors with basic education. One of the ways out of this situation was sending capable young men to study in Europe. The results were faster, but a number of problems had occurred. The studies abroad were conducted in languages that the natives of Russian Empire did not know, and there was no time for studying them. Moreover, the dispatching and maintaining of potential specialists was a very costly project. "Drawing in" foreign teachers were not cheap either, but Peter still began opening schools with foreign teachers in Russian Empire.

Yet another issue that Peter I faced, and the following rulers could not solve for more than a hundred years, was that the subjects of Russian Empire, especially those of the privileged casts, in their majority did not aspire for an education. One could put in any kind of money, bring in the best teachers and even make them attend the classes, but it proved to be extremely hard to "pour" the knowledge into noble ignoramuses. Still, the country needed specialists in different spheres, teachers, clergymen, it needed written laws by which the entire population lives, and which the same populace must know and carry out.

\section{PETER I'S UNDERSTANDING OF THE ROLE OF ORTHODOXY IN THE LIFE OF THE RUSSIAN STATE}

Could you call Peter I super-religious? Most likely, not. It is enough to remember how after the Battle of Narva he issued to melt church bells into cannons. One can understand why his subjects murmured at such unlawfulness, considering the articles of the Code that Peter himself signed, and then violated.

Just for Blasphemy, the church punished with 20 years of exile and hard labor, and less severe crimes, such as violation of the article 226, "Disrespect to the shrine", were punished by a three year imprisonment in a straight house, or a prison sentence up to a year. Distraction from faith was punished by branding, corporal punishment and an exile (depending on whenever it was violent or non-violent from 10 to 15 years). Especially severe was the punishment for not engaging kids into faith. Even if one of the parents (non-Orthodoxy) tried to raise his kid in his faith, by the article 192 of the Code he received a divorce and an exile to Siberia. For apostasy, all contacts between parents and children were prohibited. Even less can be said about punishment for children' non-baptism - it was punished up to two years.

So, to what purpose did Peter need such "draconian measures"? Dante in "Divine Comedy" pointed at the populace itself - "O animals of clay! O spirits gross I" and "more than I am wont, I rein and curb, the powers of nature in me, lest they run" [3]. His observations can be attributed to the population of Russian Empire as well. As such, Russian philosopher V.S. Soloviev wrote: "Russian idea is recognition of a Social Trinity, where each of the three primary organic Unities, Church, State and Society, is doubtlessly free not in isolation from others, absorbing and destroying them, but in affirmation of a certain inner connection to them. Restoring such a concept of the Holy Trinity on earth is a Russian idea" [4]. V.S. Soloviev thought this Social Trinity to be Church, State and Society. But let's go back to the fact that the population was, in its majority, illiterate. Orthodoxy customs and traditions had replaced the civil, and at times even criminal law. The legal system of Russian Empire, in its essence, stated Orthodoxy customs and rites. As such, without knowing the letters and having an ability to read the laws of the State, the subjects had full understanding of their rights and obligations. Every uneducated peasant serf woman who was getting married knew what duties she takes on herself. And if she doesn't get something, then during a confession the priest will explain. And if she won't come to a confession, then "for "not being on a confession" from commoners and townspeople the first time charged a ruble, the second time -2 rub., the third time - 3 rub.; from peasants respectively 5, 10 and 15 kopecks" [5]. At that time those were big, almost impossibly big money. Yet even more from violating the law could lose the clergyman, if he did not report the "absence" of one of his charge. He could be stripped of his dignity and exiled to Siberia.

Yet another reason for Peter I's understanding of importance of law-enforced Orthodoxy in the life of Russian Empire is an idea of progress itself. N.A. Berdyaev wrote that the idea of progress is rooted in religion. It "assumes a chain of historical progress and disclosure of the meaning of its dependence on this final goal" [6]. It was the progress that Peter I sought in the process of his numerous reformations. Many scientists dispute the solidarity and conflict of religion and scientific progress. As such, Berdyaev N.A. Notes: "Teaching of progress is a religious confession, a belief, because it is impossible to ground a scientifically positive teaching of progress, because only evolution can be grounded scientifically positively, while the teaching of progress can only be a subject of faith and hope" [7].

In addition, there was one more aspect that united religion (Orthodoxy) and monarchy (autocracy). French philosopher, a contemporary of Peter I named J. Bossuet wrote: "From the history of all these nations it could be seen that God created the States and gives them to those who strive for it, and that they serve His goals in accordance to His plan. Does He want to make conquerors that are preceded by fear, He inspires their warriors with unbeatable courage. Does He want to make lawmakers, He sends them wisdom and foresight. When $\mathrm{He}$ wants to ruin a nation, He blinds it and leaves it to its own foolishness. In this way, the Lord rules the nations: there is no chance on earth, no happiness". In other words, a legally enforced universal Orthodox faith had set yet another goal - an unconditional recognition of tzar as a God's Anointed and recognition of all his doings. As stated in the Gospel: "Not a single hair of your head shall perish without God's providence".

These important for the country goals, set by the lawenforced Orthodoxy, justified monotheism and sanctions for perpetrators. And with an addition of clergymen's duty to report everything they heard on a confession, the religion becomes irreplaceable tool of the State. Archpriest, Professor of Siberian Tomsk Imperial University Jacob Galakhov wrote: "Christianity does not tolerate a compromise, does not recognize half-views. Its entire worldview is straightforward, full and complete: a certain view of the worked and 
merciless revelation of its meaningless; calling a sin by its name; a struggle between the world and God, completely and incompletely naked in all the details. The main, dominant idea of Christian religious system is that every finite worldly being needs higher mediation, to unite with the God, and man himself, fully submerged in finite, with all his heart stuck to the world and its blessings, can find salvation only in atonement" [8].

Yet Peter I found it hard to categorically prohibit other faiths beside Orthodoxy since it was by his decree that foreigners arrived into Russian Empire. They, as well as citizens of non-Christian faiths were allowed to celebrate their religious rites only in particular, allowed places. The main principle of religious policy was the position that "all subjects of the Russian State of Christian foreign faiths, as well as foreigners - as Professor I.S. Berdnikov wrote - are allowed full freedom of faith and worship. Spiritual affairs of Christians of foreign faiths are managed by their own special spiritual managements, as intended by the supreme autocratic authority" [9]. At that, transition to Orthodoxy was encouraged, while leaving Orthodoxy was punishable by law same way there was a punishment for sectarianism, schism and propagation of heresy. For non-Orthodoxy preaching (in not permitted places) one could be imprisoned for up to two years in a Gray house, while "recidivists" were punished up to six years, or with an exile [10].

\section{DEVELOPMENT OF EDUCATIONAL SYSTEM IN THE RUSSIAN EMPIRE IN A POST-PETRINE ERA}

The network of educational institutions that existed since under Peter I and until the revolution of 1917, existed both somewhat secular, and strictly Orthodoxy institutions. Yet even secular institutions usually taught the Law of God. Even foreigners of other faiths, while studying in various educational installations, were obligatorily taught Orthodoxy.

Educational institutions of Russian Empire could be divided by: higher, secondary and lower, respectively universities, gymnasiums, country and parish schools. Especially should be noted special institutions - lyceums, positioned somewhere between universities and gymnasiums. With rare exceptions in separate historical periods (for example, Peter I was indifferent a young man of which social class to be taught sciences), education was classist. So, gymnasiums mainly taught the children of aristocrats. Gymnasium pupils were prepared for University education. Gymnasiums taught Latin. Someone who did not graduate gymnasium could enter a university, but he had to know Latin at the level of gymnasium pupils, since universities usually taught in that language. Country schools were for townspeople, parish schools were for peasants. In Russian Empire, education was conducted in the spirit of Orthodoxy. The Law of God was one of the obligatory subjects.

Naturally, education existed on the territory of future Russian Empire even before Peter I. For example, before joining Russian Empire, there was the University of Vilnius. Still, those institutions were a rare exception rather than a rule.
After the death of Peter I, the interest in the training of qualified specialist had significantly weakened. The institutions that opened under Peter I fell into disrepair or were outright closed. In 1731, gentry's cadet corpus had opened in St. Petersburg. There were few positions in it. For the most part, children of aristocracy were accepted in it. The majority of aristocrats' children were taught at home, and their education depended on affluence and wishes of the family. A foreign teacher could be hired for a kid, or his education could be entrusted to a local sacristan. Raznochintsy entered hospital schools to become medics, and by the middle of the $18^{\text {th }}$ century the system of theological seminary and academies grew stronger. As such, an opportunity to receive education, sometimes the only opportunity, was with individuals who were ready to be taught in theological institutions.

In post-Petrine era, in the Russian Empire were opened: Moscow University in 1755, Dorpat (Tartu) University in 1803, Kharkiv and Kazan Universities in 1804, Main Pedagogical Institute in St. Petersburg in 1816 (transformed into St. Petersburg University in 1819), Kiev University in 1833. These were secular educational institutions. Orthodoxy church had opened theological academies in Moscow, St. Petersburg, Kiev and Kazan. In other words, higher educational institutes were segregated by secular and theological. In December 1725, an Academy of Sciences was inaugurated in St. Petersburg. It was done mostly for prestige. Yet, unlike European academies, Russian Academy of Sciences was also engaged in educational tasks.

As such, in Russian Empire by the end of the 18th century, the necessity of education was accepted by nobility. Cadet corps, noble boarding schools, universities opened their doors for them; vocational schools (seminars, hospital schools) were intended mainly for raznochintsev. But women were in a special position. For centuries, gender inequality did not allow the girls in Russian Empire to receive even basic education. Before revolution of 1917 , most women were illiterate. According to the Russian Empire population census of 1897 that was recognized by native and foreign scientists, total literate were (excluding Finland) $-21.1 \%$, including $29.3 \%$ men and $13.1 \%$ women [11]. But one can't say that the issue of women's education was not in the process of solving at the state level. As such, in 1860 "Regulation about Women's schools of the Ministry of public education" was passed. Women's schools were divided in two types:

- I category -6 years of education;

- II category - 3 years of education.

The purpose of Women's education was "to give pupils that religious, moral and intellectual education that should be asked of every woman, especially of a future spouse and mother of the family". Women's schools were created by individuals and societies. They taught the Law of God, Russian language, grammar and literature, arithmetic and the concepts of measurement, general and Russian geography, history, basics of natural science and physics, calligraphy and crafts. 
By 1780s new public schools began to open. Methodical aids were commissioned from Austria and Prussia by Catherine II. In country cities, it was planned to organize two-year schools and teach reading, writing, arithmetic, the Law of God, calligraphy, and drawing. In provincial towns, the education was supposed to be four-years. Grammar, history, geography, the basics of geometry, mechanics, physics, natural history (a complex of natural science disciplines) and architecture were added to the "course of basic disciplines". It was planned that the graduates of provincial schools, after learning languages, could enter a University. But the project was not realized completely. There was a lack of teachers, finances and a lack of practical interest from commoners. Parents took their children after two classes of education. As a result, the full course was completed by just a few. As such, in Arkhangelsk Province, of 1432 pupils in 1786-1803, four years were graduated by 52 pupils. Yet, despite the incomprehension by the population, but the end of Catherine's reign there were 300 public schools in the Russian Empire, 43 of which were fouryear schools, and the number of students exceeded 17 thousand [12]. But for the Russian Empire with its population of 36 million of people it was, of course, not enough.

Yet despite the development and improvement of the education system, an entire cast deprived of these reforms existed - serf peasants. Even the most talented of them could not get an education. And even in other casts by the end of Catherine II's reign were a lot of uneducated people. And even through the reforms went on; it was not possible to fully handle illiteracy. Gradually either were lifted or set back the restrictions on Women's education, the duration of education increased.

During the reforms of Alexander II in the period from 1864 until 1872, alongside gymnasiums seven-year real schools were created, with their goal "to give the youths that studied in them general education that was adapted to practical necessities and acquisition of technical knowledge". Separately existed Women's and Men's gymnasiums and progymnasiums.

After Alexander II's abolition of serfdom, an issue of necessity of teaching peasants' children at least basic knowledge had aroused. It required Russian Empire to widen the network of educational institutions, to train teachers and to create special methodical programs. Scientific revolution, which began in the middle of XVII, exacerbated the need of education of children and youths of all casts. In prerevolutionary Russia there were military, nautical, pedagogical, agrarian, technical, commercial, artistic and other schools. During this period, the program of mandatory basic education was introduced in Russia. One of the key laws of Russian Empire was the law of May 3, 1908 "of remittance of 6.900 .000 rubles for the needs of basic education". As such, Vice-rector of Tambov Theological Seminary, Priest Victor Lisyunin, writes in his article: "The participation of the clergy in the system of public education has activated after the law as of May 3, 1908 of gradual (in a course of 10 years) introduction of mandatory universal basic education was issued" [13]. In 1905, parochial schools in the
Russian Empire made up $46.5 \%$ of all basic schools of all types, by the $1915-32.8 \%$, by the 1917 - less than a quarter [14]. Financing of education in the period from 1906 until 1914 was growing faster than defense expenditures. A separate budget line was for the salaries for the teachers of the Law of God (catecheses). By 1908 some Russian provinces had already introduced mandatory free education, and by 1921 it was supposed to be universal throughout the country. Revolution of 1917 had interrupted the existence of royal Russia and did not allow to finish this reform.

\section{CONCLUSION}

Thus, Orthodoxy in the Russian Empire carried both doctrinal, dogmatic and soul-saving contents, as well as old external State-establishing form - tradition. Orthodoxy, raised to the rank of State law, became the idea that consolidated the Russian Empire and allowed for, along with educational system, enlightenment and socialization of representatives of all casts of the Russian State.

\section{REFERENCES}

[1] Edelman O. Education in imperial Russia / Otechestvennye zapiski, 2002. №1. pp.113 - 124.

[2] Military Statistical Yearbook for 1912. SPB, 1914. p.372 - 375. Is given for publication: Russia, 1913. Statistical documentary reference. SPB. BLIZ, 1995. P. 288

[3] Dante. Divine Comedy. Minsk, 1987. P. 123.

[4] Soloviev V.S. Russian idea. Essay in 2 vol. M., V. 2. P. 245 - 246.

[5] Petrine decree of 17 February of 1718. Complete collection of laws of Russian Empire. SPB, 1830. V.5. №2991, 3169.

[6] Berdyaev N.A. The meaning of history. M., 1990. P. 145.

[7] Berdyaev N.A. The meaning of history. M., 1990. P.147.

[8] Archpriest Jacob Galakhov. Religious Studies. M., 2008. P. 246.

[9] Berdnikov I.S. A short course of ecclesiastical laws of Orthodoxy Church. 2nd ed. Kazan, 1913. Issue 2. P. 203.

[10] Berdnikov I.S. A short course of ecclesiastical laws of Orthodoxy Church. 2nd ed. Kazan, 1913. 1467 p.

[11] Kahan A. Russian economic history: the nineteenth century // University of Chicago Press, 1989. P. 244.

[12] Edelman O. Education in imperial Russia / Otechestvennye zapiski, 2002. №1. pp.113 - 124.

[13] Meaning of Orthodoxy clergy in the creation of public education at the turn of the ages (end XIX - beginning XX century.) 3 GATO. F. 126. Op. 3. D. 40.

[14] TSB, article «Tserkovno-pryhodskiye shkoly».

[15] Basic public education // New Collegiate Dictionary: Pg.: Publication AO «Publishing of the former Brockhaus-Efron», 1916. V. 28. P. 123. 